\title{
Corrigenda: Roques A, Copeland RS, Soldati L, Denux O, Auger-Rozenberg M-A (2016) Megastigmus seed chalcids (Hymenoptera, Torymidae) radiated much more on Angiosperms than previously considered. I- Description of 8 new species from Kenya, with a key to the females of Eastern and Southern Africa. ZooKeys 585: 5I-I24. doi: 10.3897/zookeys.585.7503
}

\author{
Alain Roques', Robert S. Copeland ${ }^{2,3}$, Laurent Soldati ${ }^{4}$, \\ Olivier Denux', Marie-Anne Auger-Rozenberg'
}

I INRA, UR633, Zoologie Forestière, 2163 Avenue Pomme de Pin, F-45075, Orléans, France 2 ICIPE, International Centre of Insect Physiology and Ecology, P.O. Box 30772, Nairobi 00100, Kenya 3 National Museums of Kenya, Division of Invertebrate Zoology, P.O. Box 40658, Nairobi 00100, Kenya 4 INRA, UMR 1062, Centre de Biologie pour la Gestion des Populations, Campus International de Baillarguet, CS 30016, F-34988, Montferrier-sur-Lez, France

Corresponding author: Alain Roques (alain.roques@orleans.inra.fr)

Academic editor: P. Stoev | Received 27 September 2016 | Accepted 27 September 2016 | Published 29 September 2016

http://zoobank.org/4B684B7C-5384-4CAB-9A58-DC9FCE9F5829

Citation: Roques A, Copeland RS, Soldati L, Denux O, Auger-Rozenberg M-A (2016) Corrigenda: Roques A, Copeland RS, Soldati L, Denux O, Auger-Rozenberg M-A (2016) Megastigmus seed chalcids (Hymenoptera, Torymidae) radiated much more on Angiosperms than previously considered. I- Description of 8 new species from Kenya, with a key to the females of Eastern and Southern Africa. ZooKeys 585: 51-124. doi: 10.3897/zookeys.585.7503. ZooKeys 620: 151-151. doi: 10.3897/zookeys.620.10663

On p. 81 the header for the new species reads Megastigmus pistaciae Roques \& Copeland sp. n.

The CORRECT species name is Megastigmus ozoroae Roques \& Copeland sp. n. The name was misspelled when the PDF file was generated.

Copyright Alain Roques et al. This is an open access article distributed under the terms of the Creative Commons Attribution License (CC BY 4.0), which permits unrestricted use, distribution, and reproduction in any medium, provided the original author and source are credited. 